\title{
Contributors / Collaborateurs
}


Pierre Anctil is a member of the Royal Society of Canada and a full professor in the department of history of the University of Ottawa, where he teaches contemporary Canadian history and Canadian Jewish history. He has written at length on the history of the Jewish community of Montréal and on current debates on cultural pluralism in Québec. He is the author of a literary biography of Montreal Yiddish poet Jacob-Isaac Segal, entitled Jacob-Isaac Segal (I896-1954), un poète yiddish de Montréal et son milieu (Presses de l'Université Laval, 20I2). He recently published a study of anti-Semitism in the Montréal daily Le Devoir entitled: 'À chacun ses Juifs.' 60 éditoriaux pour comprendre la position du Devoir à l'égard des Juifs I910-I947 (Septentrion, 20I4). His latest publication is Les Juifs de Québec, 400 ans d'histoire (Presses de l'Université du Québec, 2015).

Christine Barrass is the archivist responsible for the multicultural and Jewish collections at Library and Archives Canada. She was hired at LAC in 2002 as a government records archivist and moved into private records acquisition in 2008.

Antoine Burgard is finishing a PhD in History at Université Lumière Lyon 2 (France) and Université du Québec à Montréal (Canada), co-advised by Yolande Cohen and Isabelle von Bueltzingsloewen, and will start a postdoctoral research about Jewish pro-refugee activism at the University of Manchester.

Aubrey L. Glazer, PhD, is senior rabbi of Congregation Beth Sholom, San Francisco. As a graduate of the Institute for Jewish Spirituality, Aubrey co-leads Jewish meditation retreats. He publishes reflections on contemporary spirituality, Mystical Vertigo (Academic Studies Press, 2013) and his latest book explores the intersection of Jewish mysticism and Rinzai Buddhism in the songbook of Leonard Cohen, called Tangle of Matter \& Ghost: Leonard Cohen's Post-Secular Songbook of Mysticism(s) Jewish \& Beyond (Academic Studies Press, 2017).

Arlene Greenberg graduated from McGill University with a Master's in Library and Information Studies in the I970s. She began her career as a medical librarian at the Lady Davis Institute for Medical Research of the Jewish General Hospital (JGH). In 1978 she took over as the Chief Medical Librarian of the main Medical Library of the JGH, now the Health Sciences Library, and remained in the position until her retirement in 2016. Throughout her 46-year career, Arlene oversaw the complete change from print to digital, and ensured the preservation of the JGH legacy through the work of a full-time archivist, $\mathrm{Da}$ (Linda) Lei (co-author in this volume).

Simone Grossman est professeure de littérature française et québécoise à l'Université Bar Ilan. La littérature contemporaine du Québec est actuellement son principal domaine de recherche. Elle s'intéresse tout particulièrement aux écrivains migrants auxquels elle a consacré plusieurs articles. 
Robert Aaron Kenedy is an Associate Professor of Sociology at York University who studies Diaspora and resettlement in Canada.

David S. Koffman is an assistant professor in the Department of History at York University. He is a faculty affiliate of the Israel and Golda Koschitzky Centre for Jewish Studies, the Robarts Centre for Canadian Studies, and a co-editor of Canadian Jewish Studies / Études juives canadiennes.

Da (Linda) Lei graduated from the School of Information Studies at McGill University. In 2008 she started her career as an Archives Consultant at the Health Sciences Library of the Jewish General Hospital for leading a digitization project to commemorate the $75^{\text {th }}$ anniversary of the Hospital. In 201 s she became the Archivist of the Hospital, responsible for keeping a growing record of the JGH legacy, and for providing an easier access to the Archives for staff and interested public.

Saundra Lipton has over 38 years' experience as a Humanities and Social Sciences Librarian at the University of Calgary, specializing in research resources for Anthropology, Archaeology, Classical Studies, Philosophy and Religious Studies. She currently serves as President of the Jewish Historical Society of Southern Alberta.

Saara Mortensen, Archivist at the Ottawa Jewish Archives, holds an M.A. in Photographic Preservation and Collections Management, a B.A., and a degree in Museum Studies. Prior to her current tenure, Saara acquired a variety of work experiences at collecting institutions including Library and Archives Canada, the National Gallery of Canada, and the Richard and Ronay Menschel Library at the Eastman Museum in Rochester, New York.

Chantal Ringuet est écrivaine, chercheuse et traductrice littéraire. Elle est l'auteure de recueils de poésie (prix littéraire Jacques-Poirier 2009) et d'ouvrages sur le Montréal yiddish. Elle a fait paraittre un collectif sur Leonard Cohen (avec G. Rabinovitch) et une traduction de l'autobiographie de Marc Chagall (avec Pierre Anctil). Son dernier ouvrage, un essai littéraire intitulé Un pays où la terre se fragmente. Carnets de Jérusalem (LLÉ, 20I7), s'intéresse à la vie littéraire et culturelle au Proche-Orient. Elle a été boursière au YIVO, l'Institute for Jewish Research à New York, chercheure en résidence au Hadassah-Brandeis Institute, et écrivaine en résidence et traductrice en résidence (BILTC) au Banff Centre for the Arts and Creativity. 
Janice Rosen has been the Archives Director since 1989 of the Alex Dworkin Canadian Jewish Archives, formerly known as the Canadian Jewish Congress Charities Committee National Archives. Her publications include various surveys of Canadian Jewish archival resources and repositories for Canadian Jewish Studies journal. She is a co-creator of the Canadian Jewish Heritage Network, a database-driven website showcasing the holdings of several partner Archives and Museums.

Stephanie Tara Schwartz is a researcher, writer and curator specializing in Jewish diaspora and Canadian cultural studies. She has designed online and physical walking tours, interactive exhibitions and a digital trivia game as Founding Research Director of the Museum of Jewish Montreal (2012-2016) and with the Ontario Jewish Archives, Blankenstein Family Heritage Centre (2016-2017). She held a SSHRC postdoctoral fellowship (2014-2016) and is past co-editor of Canadian Jewish Studies/Études juives canadiennes (2012-2017). 